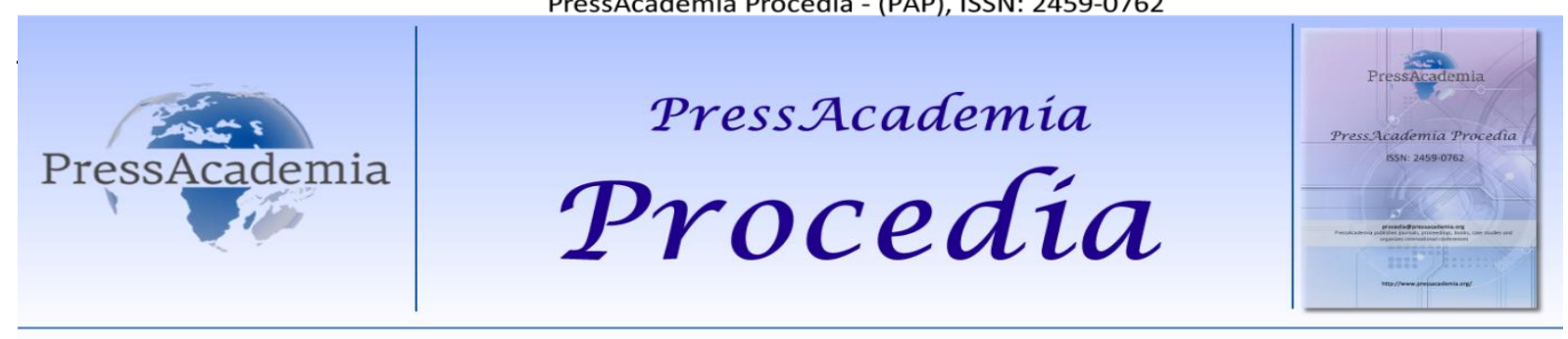

Global Business Research Congress (GBRC), May 24-25, 2017, Istanbul, Turkey.

\title{
AN EVALUATION OF TURKISH MUTUAL AND PENSION FUNDS' PERFORMANCES
}

\section{DOI: 10.17261/Pressacademia.2017.399 \\ PAP-GBRC-V.3-2017(14-p.131-142}

\author{
Jale S. Oran ${ }^{1}$, Emin Avci ${ }^{2}$, Mahmood Ashoor ${ }^{3}$, Ömer Faruk Tan ${ }^{4}$ \\ ${ }^{1}$ Marmara University, Bahçelievler, Istanbul, Turkey, jaleoran@marmara.edu.tr \\ ${ }^{2}$ Marmara University, Bahçelievler, Istanbul, Turkey, eavci@marmara.edu.tr \\ ${ }^{3}$ Marmara University, Bahçelievler, Istanbul, Turkey, mahmoodo.ashoor@gmail.com \\ ${ }^{4}$ Marmara University, Bahçelievler, Istanbul, Turkey, omer.tan@marmara.edu.tr
}

To cite this document

Oran, S. J., E. AvcI, M. Ashoor and O.F. Tan, (2017). An evaluation of Turkish mutual and pension funds's performances. PressAcademia Procedia (PAP), V.3, p.131-142.

Permemant link to this document: $h$ ttp://doi.org/10.17261/Pressacademia.2017.399

Copyright: Published by PressAcademia and limited licenced re-use rights only.

\section{ABSTRACT}

This study evaluates the performance of Turkish type-A equity mutual funds and growth equity pension funds for the period between 01.01.2009 and 31.12.2015, using the Sharpe, Sortino, Treynor, Jensen, and Information ratio models, followed by the TOPSIS (Technique for Order Preference by Similarity to Ideal Solution) model, which combines the previously mentioned evaluation techniques to reach to a comprehensive ranking of the funds. In addition, the study tests the ability of fund managers to outperform the market using Jensen's alpha and Treynor-Mazuy models. In this study, a total of 15 type-A mutual funds and 10 growth equity pension funds have been evaluated and ranked. After using the Jensen's alpha and Treynor-Muzay models, the results, in general, indicate that the managers of these funds do not possess the ability to outperform the market neither by stock selection nor by market timing. For market timing, only one pension fund has a statistically significant measure implying that its management possesses the ability to time their investments according to their expectations of the future movements of the market. On the other hand, only one mutual fund shows to have outperformed the market by stock selectivity while statistically significant at the $1 \%$ level. The study also ranked the mutual and pension funds using the Sharpe, Sortino, Treynor, Information ratio and Jensen models, followed by the TOPSIS model. On the average, pension funds seem to outperform mutual funds when Treynor, Information, and Jensen models are considered. While, when Sharpe and Sortino models are considered, mutual funds seem to outperform pension funds. In addition, it seems that mutual funds outperform pension funds when all measures are combined using the TOPSIS model.
\end{abstract}

Keywords: TOPSIS method, mutual funds, pension funds, Jensen's Alpha, market timing ability. JEL Codes: G11, G19, F39 


\section{INTRODUCTION}

One of the most studied topics in finance is the evaluation of investments' performance carried out by investment managers. It is considered as a topic of much importance for both academicians and practitioners. Academicians, in an attempt to test the validity of the market efficiency theory, examine the forecasting abilities of managers, which would enable them to achieve abnormal returns. On the other hand, practitioners use these examinations to guide them in the allocation of funds on different investments. (Henriksson \& Merton, 1981)

Mutual and pension funds are particularly considered a popular area for such research as they are operated for the sole purpose of investing. The public invests great sums of money in these mutual funds, which in turn are invested by these funds in various financial instruments, such as; stocks, bonds, real estate, gold and minerals, etc. Similarly, participants contribute their savings to be invested in pension funds, which are managed by asset management companies (Gökçen \& Yalçın, 2014). These funds are considered advantageous to investors as their investments are diversified widely, reducing their exposure to risk. In addition, these funds are managed by professionals, which supposedly have more experience than small investors.

In Turkey, mutual funds first appeared in 1987 after the formation of Istanbul Stock Exchange (ISE), now called Borsa Istanbul, in 1985. According to the Capital Markets Board of Turkey, mutual funds are open-end pools with no legal entity but their assets are separated from the founder as a safety mechanism against bankruptcy. In addition, mutual funds are exempt from corporate and income tax. In 1994, mutual funds started to be classified into two types; A and B. Type A mutual funds are obligated to invest $25 \%$ of their portfolio in stocks issued by Turkish companies, while Type B funds do not have such obligation and are free to invest without any restrictions. The latest statistics (December 2015) show that there are a total of 363 operating mutual funds, with a total asset value of 37,186,000 thousand Turkish Liras. Since 2004, the total asset value for all mutual funds increased by around 50\%. (Capital Markets Board of Turkey, 2015)

On the other hand, the pension fund system in Turkey started on October 27, 2003, which intends to strengthen the public pension system and is part of an initiative to improve the domestic savings rate in Turkey. The contribution to the individual pension system is voluntary and on the basis of defined contribution plans. Within the financial sector, the size of the private pension system has increased; pension companies are now main players in the system (Kurtaran, et. al, 2013). It plays a key role in enhancing the savings rate in the economy and contributes to the inflow of money in the financial system, thus providing an efficient allocation of resources (Acikgöz, et. al, 2015). The most important reform in the pension system was started in 2013, which introduced a $25 \%$ state contribution-where the government makes a direct contribution to participants' accounts (EGM, 2014 Report). For example, when $100 \mathrm{TL}$ is deposited as a contribution in an account, the state will contribute $25 \mathrm{TL}$; increasing savings to a total of $125 \mathrm{TL}$. The total size of the private pension system was 20.346.290 TL in 2012, increasing a year later to 26.297.484 TL (25.141.718 TL was the amount received from fund participants, and 1.151.766 TL was the state contribution). In 2014, the state contribution was 3.019.076 TL and the fund contribution was 34.793.0777 TL, amounting to a total of 37.812.54 TL. Hence, we can easily say that the state contribution vitally boosts the pension system in Turkey: the total amount almost doubled from approximately 20.36.290 TL to 37.812.154 TL in only two years.

\section{LITERATURE REVIEW}

One of the first studies that evaluated performance of mutual funds was carried out by Treynor (1965). He developed a riskadjusted indicator, which examines the quality of returns, rather than the quantity. Sharpe (1966) followed with a study that introduced another measure to evaluate performance. Instead of using the variability of returns as the measure of risk, as Treynor (1965) did using beta, he used the volatility of returns measured by the standard deviation. He evaluated 34 open-end mutual funds using both measures to find evidence that only 11 funds were able to outperform the index.

Jensen (1968) developed a model to examine the ability of stock selectivity by mutual fund managers. Jensen's alpha, the index used to measure stock selectivity, convey the portion of the mean return of the fund that is unexplained by the systematic risk exposure to market variations. By examining 115 mutual funds, he found that managers of mutual funds, generally, do not have selective abilities and funds do not outperform the market.

In an attempt to reap the benefits of the different evaluation measures (Treynor's ratio, Sharpe's ratio, Sortino's ratio, Jensen's Alpha, Information ratio, etc.) which became abundant throughout the years, researchers started using a multicriteria decision making technique, founded by Hwang and Yoon (1981), called Technique for Order Preference by Similarity to Ideal Solution (TOPSIS, for short) which combines all desired measures into one. (see: Hui. et. al. (2010), Jiuan et. al. (2007)

In their efforts to evaluate another aspect of managers' abilities, timing the market, Treynor and Mazuy (1966) developed a measure that indicates excess returns which are not explained by the current risk position of the manager. They examined 57 mutual funds finding only 1 with significant timing abilities. 
Several studies after that attempted to evaluate mutual funds' performances using such single-index models, as well as multi factor models; such as Fama-French 3 factor model and Carhart model. These studies in terms of period chosen and sample, however, they unamiously found that funds, on average, are not able to beat the market. (see: McDonald (1973), Elton, Gruber, Das, and Hlavka (1993), Malkiel (1995), Blake, Elton, and Gruber (1993), Detzler (1999), and Fama and French (2010))

Turkish case is no different that the findings in above mentioned studies. There is a significant amount of evidence, whether using single-index or multi-factor models, to suggest that funds do not outperform the market and managers do not possess timing and/or selective abilities. (see: (Gürsoy and Erzurumlu (2001), Gökçen and Yalçın (2014), Türegün and Kaya (2014)). In an attempt to compare between mutual and pension funds' performances, Akpınar (2014) and Alptekin (2009) find evidence that pension funds outperform mutual funds.

\section{DATA AND METHODOLOGY}

\subsection{Data}

This paper evaluates the performance of Turkish Type A Equity mutual funds and Equity growth pension funds with the use of available data from January 2009 till the end of December 2015. Data is acquired from the Thompson-Reuters Database. The paper only considers funds that are heavily invested in equity to evaluate the performance of managers, and evaluate whether the active management of these funds is able to outperform the market. We exclude any funds that are closed, newly established, and merged with other funds during the research period. Our final sample includes 15 type-A equity mutual funds and 10 equity growth pension funds.

\subsection{Return on Funds}

Logarithmic return of funds is calculated over daily price indices of funds. 1,565 days are analyzed for the study between January 2009 and December 2015.

$$
R_{p}=\ln \left(\frac{P_{t}}{P_{t-1}}\right)
$$

where

$R_{p}=$ return on the fund

$P_{t}=$ price of the fund at day $t$

$P_{t-1}=$ price of the fund at day $t-1$

\subsection{Benchmark}

BIST100 price index is utilized as the benchmark to assess whether a fund could outperform the market. Logarithmic daily returns of the BIST100 are used in this study.

$$
R_{m}=\ln \left(\frac{P_{m t}}{P_{m t-1}}\right)
$$

where

$R_{m}=$ returns on the BIST100

$P_{m t}=$ value of the BIST100 Price Index on day $\mathrm{t}$

$P_{m t-1}=$ value of the BIST100 Price Index on day $\mathrm{t}-1$

\subsection{Risk-free rate}

The risk-free rate is considered as the logarithmic daily returns of the Turkish governmental 3-month Treasury bills.

\subsection{Methodology}

Adopting methods from earlier research to evaluate the performance of the Turkish Type A equity mutual funds and Growth Equity/ State Borrowing Instrument Pension Funds, the study applies Sharpe, Sortino, and Treynor ratios and Jensen's alpha. Then the TOPSIS method is applied on the measures to reach to a final ranking. In addition, Jensen's alpha is also used to evaluate the managers' ability to pick stocks, while Treynor and Mazuy model is used to evaluate the timing abilities of the managers. 


\subsubsection{Sharpe Ratio}

Sharepe taio is a composite measure to evaluate risk-adjusted performance. It is calculated by deducting the risk-free rate from the rate of return of the fund, divided by the standard deviation of the fund's returns. Higher the value of this ratio, higher the return for each unit of risk, hence, a better quality of returns.

$$
S_{p}=\frac{\left(R_{p}-R_{f}\right)}{\sigma_{p}}
$$

$$
\begin{aligned}
& R_{p}: \text { Return of the fund } \\
& R_{f}: \text { Risk-free rate } \\
& \sigma_{p}: \text { Standard deviation of the fund returns }
\end{aligned}
$$

\subsubsection{Sortino Ratio}

This ratio is very similar to Sharpe ratio, but with one alteration. It uses the downside risk instead of standard deviation as the measure of risk. Standard deviation considers all volatility whether positive or negative. On the other hand, downside risk considers only the negative volatility (downside) and ignores the positive. The interpretation of this measure is identical to Sharpe, therefore the higher the better.

$$
S o_{p}=\frac{\left(R_{p}-R_{f}\right)}{D R_{p}}
$$

$R_{\mathrm{p}}$ : Return of the fund

$R_{f}$ : Risk-free rate

$D R_{p}$ : Downside risk of the fund returns

\subsubsection{Treynor Ratio}

This ratio is considered the first attempt to evaluate performance and is the base for Sharpe and Sortino's ratios. It differs from Sharpe as it uses beta instead of standard deviation as the measure of risk. Beta is concerned with the variability of a fund's returns in respect to the market return. In this measure, only systematic risk is considered as it is assumed that unsystematic risk is diversified away by investing in a multi-asset portfolio.

$$
T_{p}=\frac{\left(R_{p}-R_{f}\right)}{\beta_{p}}
$$

$$
\begin{aligned}
& R_{p} \text { : Return of the fund } \\
& R_{f}: \text { Risk-free rate } \\
& \beta_{p} \text { : Variability of the fund returns }
\end{aligned}
$$

\subsubsection{Jensen's Alpha}

This measure assumes that the Capital Asset Pricing Model (CAPM) is valid. Alpha is the measure of excess return that is unexplained by the systematic risk, which indicates a manager's predictive ability. The sign of the alpha measure indicates the stock picking ability while its value indicates the performance of the fund.

$$
R_{p}-R_{f}=\alpha_{p}+\beta_{p}\left(R_{m}-R_{f}\right)
$$

$R_{p}$ : Return of the fund

$\mathrm{R}_{\mathrm{f}}$ : Risk-free rate

$\beta_{\mathrm{p}}$ : Variability of the fund returns

$\mathrm{R}_{\mathrm{m}}$ : Return of the market

\subsubsection{Treynor \& Mazuy Model}

This quadratic model measures the ability of managers to time their investments according to their expectations about the direction of the market. If managers possess this ability, they should be able to beat the market. A positive $\beta_{1}$ (timing 
parameter) shows that managers are able to time their investments to beat the benchmark, while a negative one implies an absence of such ability.

$$
R_{p}-R_{f}=\alpha_{p}+\beta_{p 0}\left(R_{m}-R_{f}\right)+\beta_{p 1}\left(R_{m}-R_{f}\right)^{2}
$$

$$
\begin{aligned}
& R_{p} \text { : Return of the fund } \\
& R_{f}: \text { Risk-free rate } \\
& \beta_{p o} \text { : Slope of the portfolio return } \\
& R_{m} \text { : Return of the market }
\end{aligned}
$$

\subsubsection{Information Ratio}

This ratio is also similar to the Sharpe ratio, but uses the return of the market instead of the risk-free rate to calculate the excess of returns. It is calculated by deducting the rate of return of the market from the rate of return of the fund, divided by the standard deviation of the fund's returns. Higher the value of this ratio, higher the return for each unit of risk, hence, a better quality of returns.

$$
I R_{p}=\frac{\left(R_{p}-R_{m}\right)}{\sigma_{p}}
$$

$$
\begin{aligned}
& R_{p}: \text { Return of the fund } \\
& R_{m} \text { : Return of the market } \\
& \sigma_{p} \text { : Standard deviation of the fund returns }
\end{aligned}
$$

\subsubsection{TOPSIS Method}

This technique is a multi-criteria decision analysis method which primarily is utilized to solve decision making problems, more specifically; multi-attribute decision problems. The TOPSIS method basically identifies the "ideal" and "anti-ideal" solutions (which are hypothesized by the decision maker), then measures the relative distances away from the ideal and anti-ideal solutions for each alternative. The best solution should be as close as possible to the ideal solution, and as far as possible from the anti-ideal solution. To apply this method, different weights should be assigned for each criterion. This study uses the coefficient of variation (CV) as the objective weight after normalizing for unity using the following equation:

$$
C V_{j} / \sum_{k=1}^{m} C V_{k}
$$

$\mathrm{j}=1,2, \ldots, \mathrm{m}$, where $\mathrm{CV}_{\mathrm{j}}$ is the sample coefficient of variation under criterion $\mathrm{j}$.

The following steps are applied in this technique:

Step1: A normalized matrix is constructed.

$i$ : alternative, $j:$ criterion

$$
r_{i j}=\frac{x_{i j}}{\sqrt{\sum_{i} x_{i j}^{2}}}
$$

Step 2: A weighted normalized matrix is constructed.

$$
v_{i j}=w_{i} * r_{i j}
$$

Step 3: The ideal and non-ideal solutions are set for each criterion.

$I^{+}=\left(v_{1}^{+}, v_{2}^{+}, \ldots, v_{m}^{+}\right)$, maximum values.

$A I^{-}=\left(v_{1}^{-}, v_{2}^{-}, \ldots, v_{m}^{-}\right)$, minimum values.

Step 4: The distance of each alternative to the ideal and anti-ideal solutions is calculated.

$$
\begin{aligned}
& d_{i}^{+}=\sqrt{\sum_{j}^{m}\left(v_{i j}-v_{j}^{+}\right)^{2}} \\
& d_{i}^{-}=\sqrt{\sum_{j}^{m}\left(v_{i j}-v_{j}^{-}\right)^{2}}
\end{aligned}
$$


Step 5: Coefficient of closeness is calculated.

$$
C C_{i}=\frac{d_{i}^{-}}{d_{i}^{+}+d_{i}^{-}}
$$

\section{FINDINGS AND DISCUSSIONS}

\subsection{Descriptive Statistics}

Descriptive statistics of Type-A Equity Mutual and Growth Equity Pension funds, (see Appendix A) as well as of the benchmark, are shown in tables (1) and (2). Mean statistics show that 7 mutual funds and 7 pension funds have surpassed the BIST 100 benchmark during the period of the study. According to the standard deviation statistics, none of the funds in the study's population show more volatility than the benchmark, indicating that none of the funds is riskier than BIST 100 . The statistics also show that all funds have a negative skewness measure, while the benchmark shows a positive one. In addition, all funds and the benchmark show a positive kurtosis measure, which indicates heavy tailed return distributions.

Table 1: Descriptive Statistics of Type-A Equity Mutual Funds

\begin{tabular}{|c|c|c|c|c|c|c|c|c|}
\hline $\begin{array}{c}\text { Mutual } \\
\text { Funds }\end{array}$ & Mean & $\begin{array}{c}\text { Std. } \\
\text { Dev. }\end{array}$ & Kurtosis & Skewness & Min. & Max. & Beta & R`2 $^{\wedge}$ \\
\hline BIST100 & 0.00054 & 0.01517 & 3.3606 & 2.25907 & -0.11064 & 0.06895 & 0.943 & 0.80 \\
\hline MF1 & 0.00048 & 0.01230 & 4.5842 & -0.6517 & -0.10196 & 0.05353 & 0.928 & 0.95 \\
\hline MF2 & 0.00064 & 0.00952 & 8.1735 & -1.1224 & -0.08755 & 0.04735 & 0.846 & 0.86 \\
\hline MF3 & 0.00057 & 0.01053 & 6.2598 & -0.9737 & -0.07766 & 0.04959 & 0.855 & 0.89 \\
\hline MF4 & 0.00041 & 0.01182 & 5.1770 & -0.6294 & -0.09829 & 0.05854 & 0.911 & 0.93 \\
\hline MF5 & 0.00044 & 0.01082 & 4.2488 & -0.4647 & -0.08771 & 0.05437 & 0.897 & 0.94 \\
\hline MF6 & 0.00070 & 0.01343 & 3.6447 & -0.4744 & -0.09905 & 0.06179 & 0.945 & 0.94 \\
\hline MF7 & 0.00042 & 0.01287 & 4.4977 & -0.5542 & -0.1029 & 0.06644 & 0.938 & 0.95 \\
\hline MF8 & 0.00061 & 0.01091 & 6.4792 & -0.9496 & -0.08926 & 0.04632 & 0.887 & 0.91 \\
\hline MF9 & 0.00054 & 0.01116 & 5.0370 & -0.5808 & -0.09077 & 0.05515 & 0.898 & 0.93 \\
\hline MF10 & 0.00038 & 0.01208 & 3.6960 & -0.4944 & -0.08989 & 0.05863 & 0.924 & 0.95 \\
\hline MF11 & 0.00026 & 0.00962 & 5.5485 & -0.7526 & -0.07266 & 0.04877 & 0.869 & 0.92 \\
\hline MF12 & 0.00105 & 0.01409 & 5.76477 & -0.90255 & -0.11645 & 0.062173 & 0.933 & 0.9 \\
\hline MF13 & 0.00056 & 0.01385 & 3.74901 & -0.50604 & -0.10406 & 0.063328 & 0.956 & 0.95 \\
\hline MF14 & 0.00053 & 0.01069 & 7.54789 & -0.64781 & -0.09012 & 0.075762 & 0.834 & 0.84 \\
\hline MF15 & 0.00053 & 0.01209 & 4.18048 & -0.47533 & -0.09538 & 0.057499 & 0.924 & 0.95 \\
\hline
\end{tabular}

Table 2: Descriptive Statistics of Growth Equity Pension Funds

\begin{tabular}{|c|c|c|c|c|c|c|c|c|}
\hline $\begin{array}{c}\text { Pension } \\
\text { Funds }\end{array}$ & Mean & Std. Dev. & Kurtosis & Skewness & Min. & Max. & Beta & $\mathbf{R}^{\mathbf{2}}$ \\
\hline BIST100 & 0.00054 & 0.0151 & 33.606 & 22.590 & -0.1106 & 0.0689 & 0.943 & 0.80 \\
\hline PF1 & 0.00059 & 0.0132 & 29.863 & -0.3833 & -0.0923 & 0.0584 & 0.945 & 0.82 \\
\hline PF2 & 0.00053 & 0.0133 & 32.942 & -0.4644 & -0.0865 & 0.0616 & 0.943 & 0.79 \\
\hline PF3 & 0.00058 & 0.0132 & 39.823 & -0.5843 & -0.1036 & 0.0568 & 0.943 & 0.80 \\
\hline PF4 & 0.00061 & 0.0133 & 39.990 & -0.4696 & -0.1043 & 0.0635 & 0.945 & 0.80 \\
\hline PF5 & 0.00069 & 0.0132 & 37.604 & -0.4929 & -0.0980 & 0.0596 & 0.941 & 0.77 \\
\hline PF6 & 0.00072 & 0.0136 & 44.143 & -0.6407 & -0.1035 & 0.0609 & 0.944 & 0.76 \\
\hline PF7 & 0.00051 & 0.0127 & 39.538 & -0.6543 & -0.1011 & 0.0499 & 0.932 & 0.79 \\
\hline
\end{tabular}




\begin{tabular}{|c|c|c|c|c|c|c|c|c|} 
PF8 & 0.00062 & 0.0128 & 37.672 & -0.4841 & -0.0960 & 0.0574 & 0.930 & 0.78 \\
\hline PF9 & 0.00046 & 0.01314 & 36.069 & -0.4867 & -0.0899 & 0.0680 & 0.940 & 0.78 \\
\hline PF10 & 0.00058 & 0.0130 & 35.030 & -0.5283 & -0.0956 & 0.0565 & 0.941 & 0.81 \\
\hline
\end{tabular}

\subsection{Ranking of Funds}

After the application of Sharpe, Sortino, Treynor, Information, and Jensen models, the rankings for Type-A equity mutual and Growth equity pension funds are shown in tables (3) \& (4). On average, pension funds outperform mutual funds when Treynor, Information, and Jensen models are considered. While, when Sharpe and Sortino models are considered, mutual funds outperform pension funds.

Table 3: Rankings of Type-A Equity Mutual Funds

\begin{tabular}{|c|c|c|c|c|c|c|c|c|}
\hline Mutual Funds & Sharpe & Rank & Sortino & Rank & Treynor & Rank & Information & Rank \\
\hline MF1 & 0.0604 & 10 & 0.094 & 10 & 0.0008 & 10 & -0.0043 & 10 \\
\hline MF2 & 0.0949 & 1 & 0.142 & 2 & 0.0010 & 2 & 0.0112 & 3 \\
\hline MF3 & 0.0794 & 4 & 0.119 & 4 & 0.0009 & 5 & 0.0038 & 5 \\
\hline MF4 & 0.0574 & 12 & 0.089 & 12 & 0.0007 & 12 & -0.0100 & 13 \\
\hline MF5 & 0.0654 & 9 & 0.105 & 8 & 0.0007 & 11 & -0.0082 & 11 \\
\hline MF6 & 0.0717 & 7 & 0.115 & 6 & 0.0010 & 3 & 0.0123 & 2 \\
\hline MF7 & 0.0531 & 15 & 0.084 & 14 & 0.0007 & 13 & -0.0087 & 12 \\
\hline MF8 & 0.0803 & 3 & 0.122 & 3 & 0.0009 & 4 & 0.0073 & 4 \\
\hline MF9 & 0.0723 & 6 & 0.114 & 7 & 0.0009 & 7 & 0.0008 & 7 \\
\hline MF10 & 0.0533 & 14 & 0.084 & 13 & 0.0007 & 14 & -0.0126 & 14 \\
\hline MF11 & 0.0544 & 13 & 0.083 & 15 & 0.0006 & 15 & -0.0283 & 15 \\
\hline MF12 & 0.0931 & 2 & 0.143 & 1 & 0.0014 & 1 & 0.0366 & 1 \\
\hline MF13 & 0.0594 & 11 & 0.094 & 11 & 0.0008 & 8 & 0.0018 & 6 \\
\hline MF14 & 0.0741 & 5 & 0.115 & 5 & 0.0009 & 6 & -0.0004 & 9 \\
\hline MF15 & 0.0655 & 8 & 0.105 & 9 & 0.0008 & 9 & -0.0003 & 8 \\
\hline
\end{tabular}

Table 4: Rankings of Growth Equity Pension Funds

\begin{tabular}{|c|c|c|c|c|c|c|c|c|}
\hline $\begin{array}{c}\text { Pension } \\
\text { Funds }\end{array}$ & Sharpe & Rank & Sortino & Rank & Treynor & Rank & Information & Rank \\
\hline PF1 & 0.0639 & 6 & 0.06392 & 10 & 0.00089 & 6 & 0.0036 & 5 \\
\hline PF2 & 0.0595 & 9 & 0.00215 & 4 & 0.00084 & 8 & -0.0002 & 8 \\
\hline PF3 & 0.0632 & 7 & 0.00228 & 5 & 0.00089 & 7 & 0.0031 & 7 \\
\hline PF4 & 0.0651 & 4 & 0.00236 & 7 & 0.00092 & 4 & 0.0055 & 4 \\
\hline PF5 & 0.0721 & 1 & 0.00259 & 9 & 0.00101 & 2 & 0.0118 & 2 \\
\hline PF6 & 0.0719 & 2 & 0.00023 & 1 & 0.00104 & 1 & 0.0133 & 1 \\
\hline PF7 & 0.0646 & 5 & 0.00230 & 6 & 0.0009 & 5 & 0.0034 & 6 \\
\hline PF8 & 0.0608 & 8 & 0.00213 & 3 & 0.00083 & 9 & -0.0019 & 9 \\
\hline PF9 & 0.0686 & 3 & 0.00243 & 8 & 0.00094 & 3 & 0.00631 & 3 \\
\hline PF10 & 0.0549 & 10 & 0.00195 & 2 & 0.00077 & 10 & -0.0057 & 10 \\
\hline
\end{tabular}


After applying the TOPSIS technique on a decision matrix of five criteria, Sharpe, Sortino, Treynor, information and Jensen models, for each of the mutual and pension funds in the study's sample, the following rankings resulted as shown in tables (5) and (6). On average, it seems that mutual funds outperform pension funds when all measures are combined.

Table 5: Rankings of Type-A Equity Mutual Funds (TOPSIS)

\begin{tabular}{|c|c|c|}
\hline Mutual Funds & CC & Rank \\
\hline MF1 & 0.367300 & 10 \\
\hline MF2 & 0.608880 & 3 \\
\hline MF3 & 0.495100 & 5 \\
\hline MF4 & 0.280311 & 13 \\
\hline MF5 & 0.308739 & 11 \\
\hline MF6 & 0.624417 & 2 \\
\hline MF7 & 0.298935 & 12 \\
\hline MF8 & 0.547361 & 4 \\
\hline MF9 & 0.448492 & 7 \\
\hline MF10 & 0.239639 & 14 \\
\hline MF11 & 0.000451 & 15 \\
\hline MF12 & 0.995830 & 1 \\
\hline MF13 & 0.4628235 & 6 \\
\hline MF14 & 0.4297074 & 8 \\
\hline MF15 & 0.4281291 & 9 \\
\hline
\end{tabular}

Table 6: Rankings of Growth Equity Pension Funds (TOPSIS)

\begin{tabular}{|c|c|c|}
\hline Pension Funds & CC & Rank \\
\hline PF1 & 0.6031748 & 1 \\
\hline PF2 & 0.3328161 & 3 \\
\hline PF3 & 0.3321031 & 5 \\
\hline PF4 & 0.3321262 & 4 \\
\hline PF5 & 0.331631 & 6 \\
\hline PF6 & 0.3380201 & 2 \\
\hline PF7 & 0.3311111 & 7 \\
\hline PF8 & 0.3296999 & 10 \\
\hline PF9 & 0.3308752 & 8 \\
\hline PF10 & 0.3307344 & 9 \\
\hline
\end{tabular}




\subsection{Stock-Picking Ability}

Tables (7) and (8) below show the values of Jensen's alpha which indicates the stock picking ability by managers. A positive sign indicates that managers have the ability to select stocks that enables them to outperform the market. In addition, the value of the alpha indicates the performance of the fund. According to the results, only MF12 has a positive sign, which is significant at the $1 \%$ level. All the other values are not significant even at the $10 \%$ level.

Table 2: Stock-Picking ability of Type-A Equity Mutual Funds

\begin{tabular}{|c|c|c|}
\hline Mutual Funds & Jensen's Alpha & t Stat \\
\hline MF1 & 0.00000 & 0.027 \\
\hline MF2 & 0.00023 & 0.988 \\
\hline MF3 & 0.00016 & 0.738 \\
\hline MF4 & -0.00005 & -0.28 \\
\hline MF5 & -0.00007 & -0.04 \\
\hline MF6 & 0.00021 & 1.278 \\
\hline MF7 & 0.00006 & -0.41 \\
\hline MF8 & 0.00017 & 0.888 \\
\hline MF9 & 0.00009 & 0.518 \\
\hline MF10 & -0.00009 & -0.66 \\
\hline MF11 & -0.0002 & -0.95 \\
\hline MF12 & $0.00057 *$ & 2.696 \\
\hline MF13 & 0.00006 & 0.402 \\
\hline MF14 & 0.00013 & 0.5 \\
\hline MF15 & 0.00005 & 0.376 \\
\hline
\end{tabular}

$* * *, * * *$ indicates significance level at $\% 1, \% 5, \% 10$ respectively.

Table 8: Stock-Picking ability of Growth Equity Pension Funds

\begin{tabular}{|c|c|c|}
\hline Pension Funds & Jensen's Alpha & t Stat \\
\hline PF1 & 0.00009 & 0,62 \\
\hline PF2 & 0.00004 & 0,27 \\
\hline PF3 & 0.0001 & 0,56 \\
\hline PF4 & 0.00012 & 0,76 \\
\hline PF5 & 0.0002 & 1,23 \\
\hline PF6 & 0.00023 & 1,33 \\
\hline PF7 & 0.00009 & 0,61 \\
\hline PF8 & 0.00003 & 0,19 \\
\hline PF9 & 0.00014 & 0,86 \\
\hline PF10 & -0.00003 & $-0,17$ \\
\hline
\end{tabular}

$*, * *, * * *$ indicates significance level at $\% 1, \% 5, \% 10$ respectively. 


\subsection{Market-Timing Ability}

The Treynor-Muzay model market timing parameter is shown in tables (9) \& (10). According to this model, a positive $\beta_{1}$ would indicate that managers have the ability to time their investments according to their expectations of the future movement of the market. Through the analysis of the study's sample, it shows that only PF6 have a positive $\beta_{1}$; significant at the $1 \%$ level, which indicates that its management possesses the timing ability. All other fund managers do not have this timing ability, as all $B_{1}$ s are either negative and significant, or insignificant at the $1 \%, 5 \%$, and $10 \%$ levels.

Table 3: Market Timing Ability of Type-A Equity Mutual Funds

\begin{tabular}{|c|c|c|}
\hline Mutual Funds & Treynor Mazuy & t Stat \\
\hline MF1 & $-0.1304 *$ & -2.85 \\
\hline MF2 & $-0.3006^{*}$ & -4.21 \\
\hline MF3 & $-0.2487^{*}$ & -3.83 \\
\hline MF4 & $-0.1905^{*}$ & -3.69 \\
\hline MF5 & $-0.1211^{*}$ & -2.53 \\
\hline MF6 & -0.0768 & -1.52 \\
\hline MF7 & -0.0747 & -1.58 \\
\hline MF8 & $-0.2112^{*}$ & -3.59 \\
\hline MF9 & $-0.1822^{*}$ & -3.38 \\
\hline MF10 & $-0.0948 * *$ & -2.2 \\
\hline MF11 & $-0.2514^{*}$ & -4.62 \\
\hline MF12 & $-0.2013^{*}$ & -3.1 \\
\hline MF13 & $-0.0796 * * *$ & -1.7 \\
\hline MF14 & $-0.3286^{*}$ & -4.19 \\
\hline MF15 & $-0.1168 *$ & -2.54 \\
\hline
\end{tabular}

Table 10: Market Timing ability of Growth Equity Pension I

\begin{tabular}{|c|c|c|}
\hline Pension Funds & $\begin{array}{c}\text { Treyn } \\
\text { or Mazuy }\end{array}$ & t Stat \\
\hline PF1 & $\begin{array}{r}- \\
0,0559\end{array}$ & $-1,25$ \\
\hline PF2 & $\begin{array}{c}- \\
0,0948 * *\end{array}$ & $-2,006$ \\
\hline PF3 & $\begin{array}{c}- \\
0,1010^{* *}\end{array}$ & $-2,16$ \\
\hline PF4 & $\begin{array}{c}- \\
0,0876^{* * *} \\
\end{array}$ & $-1,866$ \\
\hline PF5 & $\begin{array}{r}- \\
0,06413 \\
\end{array}$ & $-1,29$ \\
\hline PF6 & $0,5908 *$ & 3,567 \\
\hline PF7 & $\begin{array}{c}- \\
0,1119^{* *} \\
\end{array}$ & $-2,35$ \\
\hline PF8 & $\begin{array}{r}- \\
0,1244^{*}\end{array}$ & $-2,59$ \\
\hline PF9 & $\begin{array}{c}- \\
0,1183^{* *} \\
\end{array}$ & $-2,46$ \\
\hline PF10 & $\begin{array}{c}- \\
0,09411^{* *}\end{array}$ & $-2,07$ \\
\hline
\end{tabular}

$*, * * * * *$ indicates significance level at $\% 1, \% 5, \% 10$

respectively. 


\section{CONCLUSION}

After the analysis of 15 Turkish type-A equity mutual funds and 10 Turkish growth equity pension funds between 1.1.2009 and 31.12.2015 using the Jensen's alpha and Treynor-Muzay model, the results, in general, indicate that the managers of these funds do not possess the ability to outperform the market either by stock selectivity nor by market timing. For market timing, only one pension fund has a statistically significant measure implying that its management possesses the ability to time their investments according to their expectations of the future movement of the market. On the other hand, only one mutual fund shows to have outperformed the market by stock selectivity, while statistically significant at the $1 \%$ level.

The study also ranked the mutual and pension funds using the Sharpe, Sortino, Treynor, Information and Jensen models, followed by the TOPSIS model. On average, pension funds seem to outperform mutual funds when Treynor, Information, and Jensen models are considered. While, when Sharpe and Sortino models are considered, mutual funds seem outperform pension funds. In addition, it seems that mutual funds outperform pension funds when all measures are combined using the TOPSIS method.

\section{REFERENCES}

Acikgöz, E., Uyguntürk, H., \& Korkmaz, T. (2015). Analysis of factors affecting growth of pension mutual funds in Turkey. International Journal of Economics and Financial Issues, vol. 5, no. 2, p. 427-433.

Akpınar, O. (2014). Performance evaluation of pension funds and mutual funds in Turkey and the timing ability of fund managers. British Journal of Economics, Finance and Management Sciences, vol. 9, no. 1, p. 73-100.

Alptekin, N. (2009). Performance evaluations of Turkish type-A mutual funds and pension stock funds by using TOPSIS method. International Journal of Economics and Finance, vol. 1, no. 2, p. 11-22.

Bireysel Emeklilik Sistemi Verileri (2014). Retrieved on December 09, 2016 from http://www.egm.org.tr/

Blake, C. R., E. J. Elton, and M. J. Gruber (1993). The performance of bond mutual funds. The Journal of Business, vol. 66, no. 3, p. $370-403$.

Capital Markets Board of Turkey. Monthly Statistical Bulletin. Retrieved on December 15, 2016 from http://www.spk.gov.tr/

Detzler, M. L. (1999). The performance of global bond mutual funds. Journal of Banking \& Finance, vol. 23, no. 8, p. $1195-1217$.

Elton E.J., Gruber M.J., Das S. and Hlavka M. (1993). Efficiency with costly information: A reinterpretation of evidence from manager portfolios. Review of Financial Studies, vol. 6, p. 1-23.

Fama E.F. and French K.R. (2010). Luck versus skill in the cross-section of mutual fund returns. Journal of Finance, vol. 65, p. $1915-1947$.

Gökçen, U., \& Yalçın, A. (2014). The case against active pension funds: Evidence from the Turkish private pension system. Retrieved on December 08, 2015 from http://papers.ssrn.com/sol3/papers.cfm?abstract id=2372059

Gürsoy, T. C., and Y. Erzurumlu (2001). Evaluation of portfolio performance of Turkish investment funds. Doğuş Üniversitesi Dergisi, vol. 4, no. 8, p. $43-58$.

Henriksson, R. D., and R. C. Merton (1981). On market timing and investment performance. II. Statistical Procedures for Evaluating Forecasting Skills. The Journal of Business, vol. 54, no. 4, p. 513-33.

Individual Pension System Progress Report. Retrieved from http://www.egm.org.tr/bes2014gr/bes2014gr en.pdf

Hui. C.C., Jiuan, L. J., Horng, L. J., \& Chen, C. M. (2010). Domestic open-end equity mutual fund performance evaluation using extended TOPSIS method with different distance approaches. Expert Systems with Applications, vol. 37, no. 6, p. $4642-4649$.

Hwang, C. L. and Yoon, K. S. (1981). Multiple Attribute Decision Making: Methods and Applications. Springer-Verlag, New York.

Jensen, M.C. (1968). The performance of mutual funds in the period 1945-1964. The Journal of Finance, vol. 23, no. 2, p. 389-416.

Jiuan, L. J., Chen, C.M., \& Hui, C. C. (2007). A comparison of usual indices and extended TOPSIS methods in mutual funds' performance evaluation. Journal of Statistics and Management, vol. 10, no. 6, p. 869-883.

Kurtaran, A., Karakaya, A., \& Dağlı, H. (2013). Improvement of private pension system in Turkey and measurement of its with DEA. International Journal of Economics and Finance, vol. 5, no. 11, p. 163-173.

Malkiel G. (1995). Returns from Investing in Mutual Funds: 1971 to 1991. Journal of Finance, vol. 50, p. 549-572.

McDonald, J. G. (1973). French mutual fund performance: Evaluation of internationally diversified portfolios. Journal of Finance, vol. 28, no. 5, p. 1161-80.

OECD Pension Funds in Figures. (2015). Retrieved on December 12, 2016 from http://www.oecd.org/finance/Pension-funds-pre-data2015.pdf 
Sharpe, W. (1966). Mutual fund performance. The Journal of Business, vol. 39, no. 1, p. 119-138.

Treynor, J. L. (1965). How to rate management of investment funds. Harvard Business Review, vol. 43, no. 1, p. 63-75.

Treynor, J. L., \& Mazuy, K.K. (1966). Can mutual funds outguess the market? Harvard Business Review, vol. 44, p. $131-136$.

Türegün, N., \& Kaya, C. T. (2014). Performance evaluation of Turkish pension mutual funds. International Journal of Economics, Finance and Management, vol. 3, no. 1, p. 22-27.

\section{Appendix A}

\begin{tabular}{|c|c|c|}
\hline$\#$ & Fund's Name & Code \\
\hline 1 & AKBANK & MF1 \\
\hline 2 & ALTERNATIF BANK & MF2 \\
\hline 3 & BMD & MF3 \\
\hline 4 & DENIZ BANK & MF4 \\
\hline 5 & ECZACIBASI & MF5 \\
\hline 6 & FINANS BANK & MF6 \\
\hline 7 & GARANTI BANK & MF7 \\
\hline 8 & GEDIK & MF8 \\
\hline 9 & ING BANK & MF9 \\
\hline 10 & IS BANK & MF10 \\
\hline 11 & SEKER BANK & MF11 \\
\hline 12 & STRATEJI EQUITIES & MF12 \\
\hline 13 & TED BANK & MF13 \\
\hline 14 & TEKSTIL BANK & MF14 \\
\hline 15 & YAPI KREDI & MF15 \\
\hline 16 & ALLIANZ LP & PF1 \\
\hline 17 & ANADOLU & PF2 \\
\hline 18 & AVIVASA & PF3 \\
\hline 19 & BNPP CARDIF & PF4 \\
\hline 20 & CIGNA FINANS & PF5 \\
\hline 21 & ERGO & PF6 \\
\hline 22 & GARANTI & PF7 \\
\hline 23 & GROUPAMA & PF8 \\
\hline 24 & ING & PF9 \\
\hline 25 & VAKIFBANK & PF10 \\
\hline
\end{tabular}

